\title{
OPTIMALISASI KEPUASAN PENGGUNA SISTEM INFORMASI PERPUSTAKAAN MELALUI TEORI DELONE MCLEAN
}

\author{
Wahyu Hariyanto \\ Jurusan Perpustakaan dan Ilmu Informasi Fakultas Sains dan Teknologi \\ UIN Maulana Malik Ibrahim Malang \\ Jalan Gajayana No. 50 Malang 65144 \\ wahyuhariyanto@uin-malang.ac.id
}

\begin{abstract}
Abstrak - Dalam beberapa tahun kebelakang ini penggunaan sistem informasi sangat dibutuhkan untuk meningkatkan efisiensi kegiatan di perpustakaan. Penerapan Sistem informasi di perpustakaan dianggap mempengaruhi layanan perpustakaan terhadap pengguna. Dalam penelitian ini fokus pembahasannya adalah untuk memperdalam variable-variabel yang ada di dalam teori kepuasan pengguna sistem informasi yang dikemukaan oleh Delone Mclean. Proses pengambilan data menggunakan sampel yaitu Pegawai SMK Negeri 5 Kota Malang sejumlah 106 orang yang didasarkan pada perhitungan menggunakan rumus Slovin. Berdasarkan hasil penelitian dapat disimpulkan bahwa terdapat pengaruh antara Kualitas Informasi, Kualitas Sistem dan Kualitas Layanan terhadap Kepuasan Pengguna. Kualitas Layanan merupakan variabel paling dominan dalam mempengaruhi kepuasan pengguna.
\end{abstract}

Kata kunci: Delone Mclean, kepuasan pengguna, sistem informasi perpustakaan

\section{Pendahuluan}

Dalam perkembangannya, sistem informasi menjadi bagian yang tidak dapat dipisahkan dalam kehidupan sehari-hari khususnya dalam bidang pendidikan. Untuk menigkatkan keberhasilan dalam persaingan pada lingkungan pendidikan, perlu strategi akademik berorientasi pasar sehingga dapat mengantisipasi segala keinginan dan kebutuhan mahasiswa (Cravens, 2006). Penerapan sistem informasi saat ini adalah salah satu komponen utama bagi sekolah untuk bersaing memberikan pelayanan yang terbaik bagi siswanya. Davis (1991) mendefinisikan "Sistem informasi adalah suatu sistem yang menerima input data dan instruksi, mengolah data sesuai dengan instruksi dan mengeluarkan hasilnya". Pandangan yang dikemukaan oleh Sidharta (1995), mendefinisikan Sistem informasi adalah sebuah sistem yang di buat oleh manusia yang isinya berupa serangkaian komponen - komponen terpadu dan manual yang bertujuan untuk mengolah dan mengumpulkan data sehingga menghasilkan informasi yang berguna bagi manusia.

Menurut teori DeLone \& McLean (1992) kesuksesan sistem informasi didukung dengan beberapa variable utama antara lain variable kualitas informasi, variable kualitas sistem, variable kepuasan pengguna, variable penggunaan, variable dampak individu serta variable dampak organisasi. DeLone \& McLean (1992) menjelaskan kualitas sistem merupakan kemampuan hardware, software, kebijakan, prosedur dari sistem informasi dapat menyediakan informasi kebutuhan pengguna yang didasarkan pada seberapa baik performa dari sistem tersebut. Sistem informasi dapat dikatakan sukses 
apabila adanya peningkatan penggunaan informasi untuk membuat dan menyajikan laporan dalam pembuatan suatu keputusan (DeLone \& McLean, 1992). Sistem informasi dapat dikatakan sukses apabila diukur dari perspektif informasi yang dihasilkan oleh sebuah sistem. Kesuksesan dapat diukur dari persepsi kegunaan informasi yang dihasilkan dari sistem. Kesuksesan sebuah sistem informasi dapat dinilai dari seberapa baik sistem dan informasi sehingga dapat menjadikan sistem dan informasi tersebut sebagai kebutuhan bagi pengguna.

Pengembangan penelitian atas model awal pada tahun 1992, yang diperbarahui pada tahun 2003 dimana DeLone \& McLean menambahkan variable kualitas layanan. Selain itu merubah variabel organizational dan impact individual impact menjadi variabel net benefit. Kualitas Layanan (Sevice Quality) adalah layanan yang diberikan oleh pengembang sistem informasi (DeLone \& McLean, 2003). Kepuasan Pengguna adalah respon pemakai terhadap penggunaan keluaran sistem informasi (DeLone \& McLean, 2003). Delone \& Mclean Models menyebutkan bahwa kualitas informasi, sistem dan layanan akan berpengaruh pada pengguna kepuasan pengguna, selanjutya berpengaruh pada net benefit (Delone \& Mclean, 2003).

Sistem Informasi Perpustakaan adalah sistem informasi yang dikembangkan untuk memudahkan staff perpustakaan dalam melayani pengguna dan mengelola perpustakaan. Sistem informasi perpustakaan dapat menyajikan informasi terkait katalog buku online (OPAC), manajemen keanggotaan, sirkulasi buku (peminjaman, pengembalian dan reservasi), laporan bulanan, statistic pengunjung, manajemen user, pengelolaan media digital, dan menyediakan berbagai bahasa pengantar. Dari hasil pengamatan awal permasalahan yang terjadi dalam sistem informasi SMK Negeri 5 Malang adalah belum sinkronnya data jumlah buku yang tersedia dengan data yang ada di dalam sistem, ada beberapa kartu anggota yang tidak bisa tercetak, daftar hadir siswa masih menggunakan manual, keterlambatan peminjaman buku belum terkoneksi dengan nomor whatsapp siswa. Hal ini menyebabkan transaksi data menjadi tidak lancar, pengambilan keputusan menjadi terlambat dan kinerja penggunaan sistem informasi perpustakaan kurang maksimal.

Berdasarkan permasalahan yang ditemukan di lapangan, penelitian ini dilakukan untuk menilai efektifitas penerapan sistem informasi dalam peningkatan kepuasan pengguna sistem. Kepuasan pengguna yang dinilai berdasarkan variabel-variabel yang ada di dalam teori Delone Mclean.

\section{Tinjauan Pustaka}

Kepuasan pengguna sistem informasi menurut teori Delone McLean (2003) dipengaruhi oleh variable Kepuasan Terhadap Informasi, Kepuasan Terhadap Sistem dan Kepuasan Terhadap Layanan. Dalam variable kepuasan informasi terdapat indikator informasi yang lengkap (completeness), informasi yang akurat (accurate), informasi disajikan sesuai dengan format (format), informasi yang tepat waktu (timeliness) dan informasi yang relevan (relevance). Sedangkan variabel kepuasan terhadap sistem terdapat indikator sistem handal dalam menjalankan proses (reliability), mudah dalam 
menggunakan sistem (ease of use), sistem cepat untuk diakses(response time), sistem aman digunakan (security), dan fleksibilitas sistem (flexibility). Variabel Kepuasan Terhadap Layanan terdapat indikator layanan secara langsung (tangibles), jaminan terhadap layanan (assurance), empati terhadap layanan (empathy), layanan dapat dihandalkan (service reliability) dan daya tangkap layanan (responsiveness).

\section{Metode Penelitian}

a. Desain penelitian.

Penelitian ini menggunakan metode survey dengan mengumpulkan informasi sumber primer. Survey yang disebarkan berupa kuesioner dengan pertanyaan meliputi penggunaan sistem informasi perpustakaan di smk negeri 5 malang. Penelitian yang lakukan bersifat kuantitatif serta pengumpulan data menggunakan simple random sampling untuk memudahkan pengukuran. Tujuan dari pengumpulan data adalah untuk mengetahui seberapa besar pengaruh kualitas sistem informasi perpustakaan terhadap kepuasan pengguna sistem.

b. Sampel

Sampel dalam penelitian ini adalah Pegawai SMK Negeri 5 Kota Malang sebanyak 106 orang berdasarkan perhitungan dengan menggunakan rumus Slovin. Adapun rinciannya adalah Kepala Sekolah dan Wakil Kepala Sekolah 4 orang, guru 82 dan staf tata usaha 20.

c. Analisa data

Pada penelitian ini analisis data yang digunakan adalah analisis deskriptif yang bertujuan untuk mengkaji gambaran dari suatu variabel. Hasil Wawancara berupa kuesioner yang dijawab oleh sampel. Jawaban kuesioner disajikan dengan menggunakan skala Likert. Poin 5 atau tertinggi mewakili persepsi sangat setuju terhadap indikator sampai dengan poin 1 atau terendah dengan pernyataan sangat tidak setuju. Setelah diperoleh hasil wawancara selanjutnya data ditabulasi serta dilakukan uji validitas dan reliabilitas. Selanjutnya menggunakan program SPSS data diolah untuk membuktikan hipotesis penelitian dengan teknik analisis regresi untuk masing-masing nilai skor faktor variabel endogen terhadap eksogennya. Terdapat 3 pengujian regresi antara lain Uji Hipotesis 1 atau Uji F (Over all test), Uji Hipotesis 2 atau Uji t (individu test) dan Variabel yang Dominan.

\section{Hasil dan Pembahasan}

a. Karakteristik responden

Mayoritas responden yang usianya 41 tahun sampai 50 tahun sebanyak 37 orang (34\%). Sedangkan yang lain usianya 21 tahun sampai 30 tahun sebanyak 24 orang (23\%), usia 31 tahun sampai 40 tahun sebanyak 23 orang (22\%) dan usia 51 sampai 60 sebanyak 22 orang (21\%). Responden mayoritas berjenis kelamin laki-laki dengan jumlah 57 orang (54\%). Sedangkan 
sisanya berjenis kelamin perempuan dengan jumlah 49 orang (46\%). Mayoritas responden dengan tingkat pendidikan S1 sebanyak 87 orang (82\%). Sedangkan sisanya tingkat pendidikan S2 sebanyak 19 orang (17\%). Mayoritas responden dengan lama kerja 1 tahun sampai 10 tahun sebanyak 54 orang (53\%). Sedangkan sisanya dengan lama kerja 21 tahun sampai 30 tahun sebanyak 27 orang (25\%), 11 tahun sampai 20 tahun sebanyak 16 orang (15\%) dan 31 tahun sampai 40 tahun sebanyak 9 orang ( $7 \%)$.

b. Pengujian instrument

Hasil pengujian dari semua butir pertanyaan terhadap variabel yang telah diukur dinyatakan valid dan reliabel. Di buktikan dengan setiap nilai $r$ hitung $>$ dari $r$ tabel $(0,195)$ salain itu nilai chronbach's Alpha > dari 0,6.

c. Analisis regresi berganda

Metode ini digunakan untuk melihat pengaruh antara variable bebas (X). Dalam hal ini variabel bebas tersebut adalah kualitas informasi (X1), kualitas sistem (X2), kualitas layanan (X3) terhadap variabel terikat kepuasan pengguna(Y). Statistik inferensial yang digunakan dalam analisis data adalah dengan menggunakan analisis regresi. Menurut gujarati (1997) model matematis dari fungsi regresi hubungan antara variabel $\mathrm{X}$ dan variabel $\mathrm{Y}$ adalah sebaga berikut:

Model satu :

$\mathrm{Y}=\alpha+\beta 1 \mathrm{X} 1+\beta 2 \mathrm{X} 2+\beta 3 \mathrm{X} 3+\varepsilon$

Keterangan :

$\mathrm{Y}=$ Kepuasan pengguna

$\alpha \quad=$ Konstansta

$\beta 1, \beta 2, \beta 3=$ Koefisien Regresi

$\mathrm{X} 1 \quad=$ Kualitas informasi

$\mathrm{X} 2 \quad=$ Kualitas sistem

X3 = Kualitas layanan

$\varepsilon \quad=$ Nilai Residu

Tabel 1. Hasil dari Analisis Regresi Linier Berganda

\begin{tabular}{|l|l|l|l|l|}
\hline Variabel & $\begin{array}{l}\text { Koefisien } \\
\text { Regresi }\end{array}$ & $\begin{array}{l}\text { T } \\
\text { hitung }\end{array}$ & Sig. & Keterangan \\
\hline Kualitas informasi (X1) & 0,349 & 6,321 & 0,00 & Signifikan \\
Kualitas sistem (X2) & 0,274 & 3,569 & 0,01 & Signifikan \\
Kualitas layanan (X3) & 0,674 & 9,909 & 0,00 & Signifikan \\
\hline Konstanta & $-5,786$ & & & \\
R Square & 0,887 & & & \\
R & 0,942 & & & \\
F Hitung & 267,300 & & & \\
Sig. F & 0,000 & & & \\
N & 106 & & \\
\hline Variabel terikat $=$ Kepuasan pengguna (Y) \\
\hline F tabel=2,69 (3,102, $\alpha=0,05)$ \\
T tabel=1,98 (df $=102, \alpha=0,05)$ \\
\hline
\end{tabular}


Diperoleh persamaan regresi berganda berdasarkan tabel di atas adalah $\mathrm{Y}=-5,786+0,349 \mathrm{X} 1+$ $0,274 \mathrm{X} 2+0,674 \mathrm{X} 3+\varepsilon$. Hasil penelitian membuktikan bahwa kualitas informasi, kualitas sistem dan kualitas layanan bersama-sama mempengaruhi kepuasan pengguna. Kualitas informasi dibentuk dari informasi yang lengkap (completeness), informasi yang akurat (accurate), informasi disajikan sesuai dengan format (format), informasi yang tepat waktu (timeliness) dan informasi yang relevan (relevance). Hal utama yang membentuk Kualitas informasi adalah informasi yang lengkap (completeness). Kualitas sistem dibentuk dari sistem handal dalam menjalankan proses (reliability), mudah dalam menggunakan sistem (ease of use), sistem cepat untuk diakses(response time), sistem aman digunakan (security), dan fleksibilitas sistem (flexibility). Hal utama yang membentuk Kualitas sistem adalah mudah dalam menggunakan sistem (ease of use). Kualitas layanan dibentuk dari layanan secara langsung (tangibles), jaminan terhadap layanan (assurance), empati terhadap layanan (empathy), layanan dapat dihandalkan (service reliability) dan daya tangkap layanan (responsiveness). Hal utama yang membentuk Kualitas layanan adalah empati terhadap layanan (empathy). Mengingat hal tersebut dirasakan langsung oleh pengguna sehingga bila terdapat peningkatan kualitas informasi, kualitas sistem dan kualitas layanan maka terjadi peningkatan kepuasan pengguna.

Berdasarkan hasil penelitian terbukti bahwa kualitas informasi, kualitas sistem dan kualitas layanan berpengaruh langsung terhadap kepuasan pengguna sistem informasi perpustakaan SMK Negeri 5 Malang secara parsial. Hasil analisis deskriptif kualitas sistem menunjukkan bahwa jawaban masing-masing kelima indikator terbukti rata-rata responden cenderung setuju dengan kelima faktor tersebut. Indikator yang memberikan peranan terbesar pada kualitas informasi adalah informasi yang lengkap (completeness) yang meliputi informasi yang dihasilkan sesuai dengan kebutuhan dan informasi yang dihasilkan sangat lengkap. Sedangkan yang perlu ditingkatkan dan dikembangkan lagi adalah informasi yang akurat (accurate) yang meliputi keakuratan informasi yang dihasilkan oleh sistem informasi perpustakaan.

Hasil analisis deskriptif kualitas sistem menunjukkan bahwa jawaban masing-masing kelima indikator terbukti rata-rata responden cenderung setuju dengan kelima faktor tersebut. Indikator yang memberikan peranan terbesar pada kualitas informasi adalah pengguna mudah dalam menggunakan sistem (ease of use) yang meliputi sistem informasi perpustakaan dapat mempermudah dan menghemat waktu pekerjaan. Yang perlu ditingkatkan dan dikembangkan lagi adalah sistem cepat untuk diakses (response time) yang meliputi kecepatan sistem dalam mengakses, mengunduh dan mengunggah data.

Hasil analisis deskriptif kualitas layanan menunjukkan bahwa jawaban masing-masing kelima indikator terbukti rata-rata responden cenderung setuju dengan kelima faktor tersebut. Indikator yang memberikan peranan terbesar pada kualitas layanan adalah empati terhadap layanan (empathy) yang meliputi staf perpustakaan selalu mendengar setiap keluhan yang ada, ramah terhadap pegawai, sopan terhadap pegawai, dan paham terhadap masalah yang ada. Sedangkan yang perlu 
ditingkatkan dan dikembangkan lagi adalah jaminan terhadap layanan (assurance) yang meliputi staf selalu berada di kantor, masalah diselesaikan tepat waktu, dan kredibilitas bagus.

Penelitian ini membuktikan bahwa kualitas layanan (X3) merupakan variabel yang berpengaruh paling dominan terhadap Kepuasan pengguna sistem informasi perpustakaan (Y). Dapat diartikan bahwa untuk meningkatkan kepuasan pengguna sistem informasi perpustakaan pihak Staf perpustakaan perlu mempertahankan kualitas layananyang diberikan kepada pegawai SMK Negeri 5 Malang. Kualitas layanan yang diberikan meliputi staf perpustakaan menguasai permasalahan yang ada, staf perpustakaan lebih cepat dalam merespon keluhan, staf perpustakaan selalu ada di kantor setiap saat dan ramah kepada pegawai.

Variabel yang perlu ditingkatkan adalah kualitas informasi dan kualitas sistem. Kualitas sistem meliputi sistem dapat mempermudah pekerjaan, dapat diakses dimanapun, proses data cepat, terdapat back up data dan keamanan terjamin. Kualitas informasi meliputi informasi dapat disajikan secara lengkap, informasi mudah dibaca, informasi sesuai dengan kebutuhan data tepat dan akurat, serta penyampaian informasi tepat waktu. Sehingga dengan ditingkatkan varibel kualitas sistem dan kualitas informasi, maka dapat meningkatkan kepuasan pengguna sistem informasi perpustakaan Smk Negeri 5 Malang pada masa yang akan datang.

\section{Kesimpulan}

Hasil penelitian dapat disimpulkan bahwa kualitaas informasi dibentuk dari informasi yang lengkap (completeness), informasi yang akurat (accurate), informasi disajikan sesuai dengan format (format), informasi yang tepat waktu (timeliness) dan informasi yang relevan (relevance). Hal utama yang membentuk Kualitas informasi adalah informasi yang lengkap (completeness). sistem handal dalam menjalankan proses (reliability), mudah dalam menggunakan sistem (ease of use), sistem cepat untuk diakses(response time), sistem aman digunakan (security), dan fleksibilitas sistem (flexibility). Hal utama yang membentuk Kualitas sistem adalah pengguna mudah dalam menggunakan sistem (ease of use). Kualitas layanan dibentuk dari layanan secara langsung (tangibles), jaminan terhadap layanan (assurance), empati terhadap layanan (empathy), layanan dapat dihandalkan (service reliability) dan daya tangkap layanan (responsiveness). Hal utama yang membentuk Kualitas layanan adalah empati terhadap layanan (empathy).

Kualitas informasi, kualitas sistem dan kualitas layanan berpengaruh terhadap kepuasan pengguna sistem informasi perpustakaan SMK Negeri 5 Kota Malang. Hal ini berarti Kualitas informasi, Kualitas sistem dan Kualitas layanan dapat meningkatkan kepuasan pengguna sistem informasi perpustakaan SMK Negeri 5 Kota Malang.

Kualitas layanan berpengaruh dominan terhadap kepuasan pengguna sistem informasi perpustakaan SMK Negeri 5 Kota Malang. Hal ini berarti untuk meningkatkan kepuasan pengguna 
sistem informasi perpustakaan SMK Negeri 5 Kota Malang maka kualitas sistem dan kualitas informasi harus ditingkatkan.

\section{Daftar Pustaka}

Cravens, D.W. and Piercy, N.F.2006.Strategic Marketing (8thed.). New York .

DeLone, W. H., McLean, E. R. 1992. Information Systems Success: The Quest for the Dependent Variable. Information System Res., vol. 3, no. 4,page : 60-95. 2003. The DeLone and McLean Model of Information Systems Success : A Ten-Year Update. Journal Management Information System. Vol. 19(4) page : 9-30.

Davis, Gordon B.1991. Kerangka Dasar Sistem Informasi Manajemen Bagian 1. Jakarta : PT Pustaka Binamas Pressindo.

Gujarati, 1997. Statistik Ekonometrika. Jakarta : Bumi Aksara.

Sidharta, Lani. 1995. Pengantar Sistem Informasi Bisnis, Jakarta : PT. Elex Media Komputindo. 